\title{
Therapeutic Role of Tiotropium in Chronic Obstructive Airways Diseases
}

\author{
David M.G. Halpin, MA, DPhil, MBBS, FRCP
}

Department of Respiratory Medicine, Royal Devon and Exeter Hospital, Exeter, United Kingdom

\section{ABSTRACT}

Chronic obstructive airways disease (COPD) and asthma are major causes of morbidity around the world. This review examines the evidence on the effectiveness of tiotropium as a treatment for COPD and asthma. It discusses the role of acetylcholine in airway physiology and the effects of muscarinic antagonism on airways smooth muscle, mucous secretion and inflammation. In COPD, tiotropium increases forced expiratory volume in 1 second $\left(\mathrm{FEV}_{1}\right)$ and reduces hyperinflation; it improves breathlessness, exercise capacity and health status, and it reduces exacerbation rates. Tiotropium also reduces the rate of decline in $\mathrm{FEV}_{1}$ over 4 years in patients with an $\mathrm{FEV}_{1}$ over $50 \%$ predicted. In asthma, when added to inhaled steroids alone or in combination with long-acting beta agonists, tiotropium improves lung function, improves asthma control and reduces exacerbations. These effects have been seen in children, adolescents and adults with asthma. Tiotropium is well tolerated, with a low incidence of adverse events. (BRN Rev. 2018;4:135-52)

Corresponding author: David M.G. Halpin, d.halpin@nhs.net

Key words: Asthma. Bronchodilator. Chronic obstructive pulmonary disease. Tiotropium. 


\section{INTRODUCTION}

Asthma and chronic obstructive pulmonary disease (COPD) are both common chronic diseases characterised by airflow obstruction. COPD is now the third most common cause of death worldwide ${ }^{1}$ and the Global Burden of Disease project estimated that COPD affected 174 million people worldwide in 2015 causing 3.2 million deaths, an increase of $11.6 \%$ compared with 1990. Asthma affected 358 million people worldwide and caused 400,000 deaths, a decrease of $26.7 \%$ from $1990^{2}$.

Long-acting bronchodilators are the mainstay of treatment for $\mathrm{COPD}^{3}$ and now play an important role alongside inhaled corticosteroids (ICS) in reducing symptoms in patients with uncontrolled asthma ${ }^{4}$. Tiotropium bromide was the first long-acting muscarinic antagonist (LAMA) to be approved for maintenance treatment of COPD. It has been available since 2002, and it is widely prescribed in over 110 countries worldwide with patient experience of over 25 million patient-years 5 . It is available in two formulations: dry powder (18 $\mu$ g once daily) delivered via the HandiHaler inhaler, and aqueous solution ( $5 \mu \mathrm{g}$, two puffs $2.5 \mu \mathrm{g}$ once daily) delivered via the Respimat Soft Mist Inhaler. Since 2014, tiotropium in the Respimat has also been licensed in the European Union (EU) for addon maintenance treatment of adults with symptomatic asthma and it is still the only LAMA to have this indication. This review examines the evidence on the efficacy and safety of tiotropium in COPD and asthma, considers this in the context of the evidence on the efficacy of other LAMAs in COPD and briefly examines the efficacy of tiotropium when combined with the long-acting $\beta 2$-agonists (LABA) olodaterol.
Acetylcholine is synthesized from choline and acetyl coenzyme A mainly by the enzyme choline acetyltransferase which is expressed parasympathetic neuron in the airways but also in airway epithelial cells ${ }^{6-8}$. Human airways contain M1, M2, and M3 muscarinic receptors. M3 receptors mediate acetylcholine's effects on airway smooth muscle tone and mucous secretion from mucosal glands. M2 receptors have an inhibited auto-regulatory effect on the release of acetylcholine from both pre- and post-ganglionic nerve terminals but are also widely expressed by other cells such as fibroblasts and smooth muscle cells ${ }^{9}$. Non-neuronal acetylcholine released from epithelial cells acts as a paracrine/autocrine hormone maintaining cellular homeostasis and epithelial repair, regulating ciliary activity and mucociliary clearance and modulating the activity of inflammatory cells promoting their survival and cytokine release ${ }^{7,10}$.

Tiotropium antagonises all three muscarinic receptors present in the airways, but it has a higher selectivity for M3 receptors than for M2 receptors, and it dissociates more slowly from M3 receptors than from M2 receptors giving it its long duration of action ${ }^{11}$.

M3 antagonism leads to airway smooth muscle relaxation and a reduction in mucus secretion, which is important, as hypersecretion may contribute to airflow limitation in asthma and COPD, and it is a risk factor for accelerated loss of lung function and exacerbations ${ }^{12}$. Animal studies have suggested tiotropium might improve airflow limitation by reducing airway mucus as well as its effects on smooth muscle $^{13}$, and in patients with COPD, tiotropium was associated with a reduction in sputum volume ${ }^{14}$. 
Both asthma and COPD are characterised by chronic inflammation and structural changes to the airways, although the underlying inflammatory processes differ between each disease $^{15}$. Inflammation is an important therapeutic target for these diseases and in invitro and in animal models, tiotropium also appears to have anti-inflammatory properties due to M3 antagonism. In animal models pretreatment with tiotropium reduces eosinophilic inflammation in response to allergen exposure and partly prevents aspects of airway remodelling, inhibiting mucus gland hypertrophy and decreasing the number of MUC5AC-positive goblet cells, as well as reducing airway smooth muscle thickening ${ }^{13-16}$. In animal models, tiotropium also inhibits neutrophil chemotactic activity, and decreases levels of cytokines (interleukin [IL]-4, IL-5, IL-13 \& tumour necrosis factor alpha [TNF- $\alpha]$ ) and leukotriene B4 in bronchoalveolar lavage fluid ${ }^{17,18}$ as well as inhibiting airway remodelling and pulmonary inflammation in a guinea pig model of $\mathrm{COPD}^{18}$.

Tiotropium may also have an indirect effect on inflammation in COPD through the suppression of repeated airway smooth muscle contraction, which reduces the inflammatory activity ${ }^{9,11}$. In humans, tiotropium attenuates reactive oxygen species (superoxide anions) and leukotriene $\mathrm{B} 4$ production by peripheral blood neutrophils obtained from patients with $\mathrm{COPD}^{18}$.

\section{CLINICAL EFFECTS OF TIOTROPIUM IN COPD}

The goal of COPD therapy is to obtain improve symptoms, exercise capacity and quality of life as well as minimising or preventing exacerbations, with minimal adverse events ${ }^{3}$. Tiotropium is widely used around the world to help deliver these goals. There is now experience of over 50 million patient-years of treatment ${ }^{19}$, including more than 2.5 million patient-years' experience with the Respimat ${ }^{20}$. Its use is supported by evidence from over 200 clinical trials and of many these trials include patients typical of those seen in primary care ${ }^{21,22}$. Populations studied have included patients with mild to very severe airflow obstruction ${ }^{22}$, patients naïve to maintenance therapy ${ }^{23,24}$, patients with common and relevant comorbidities, such as cardiovascular disease ${ }^{22,25-27}$ as well those with mild-to-moderate renal impairment ${ }^{22}$.

As well as the individual clinical trials, a number of systematic reviews with meta-regression analysis of pooled data have summarised the efficacy of tiotropium in patients with COPD ${ }^{19,28-34}$ as well as its safety ${ }^{35,36}$. This review will not duplicate these reviews but will highlight the main findings.

Randomised trials have demonstrated lung function improvements with tiotropium versus placebo and active comparators. Lung function improvement is seen in patients with all levels of spirometric impairment and in all Global Initiative for Chronic Obstructive Lung Disease (GOLD) groups ${ }^{20,37-39}$. Whether administered in the HandiHaler or Respimat device tiotropium results in similar spirometric improvements ${ }^{40}$. The magnitude of the effect of tiotropium on $\mathrm{FEV}_{1}$ (whether peak or trough) compared to placebo or other bronchodilators is remarkably consistent despite differences in the characteristics of the patients studied. Figure 1 shows the effect of tiotropium on trough $\mathrm{FEV}_{1}$ compared with placebo across eighteen of the principal studies, which varied in the severity of airflow obstruction and GOLD group 


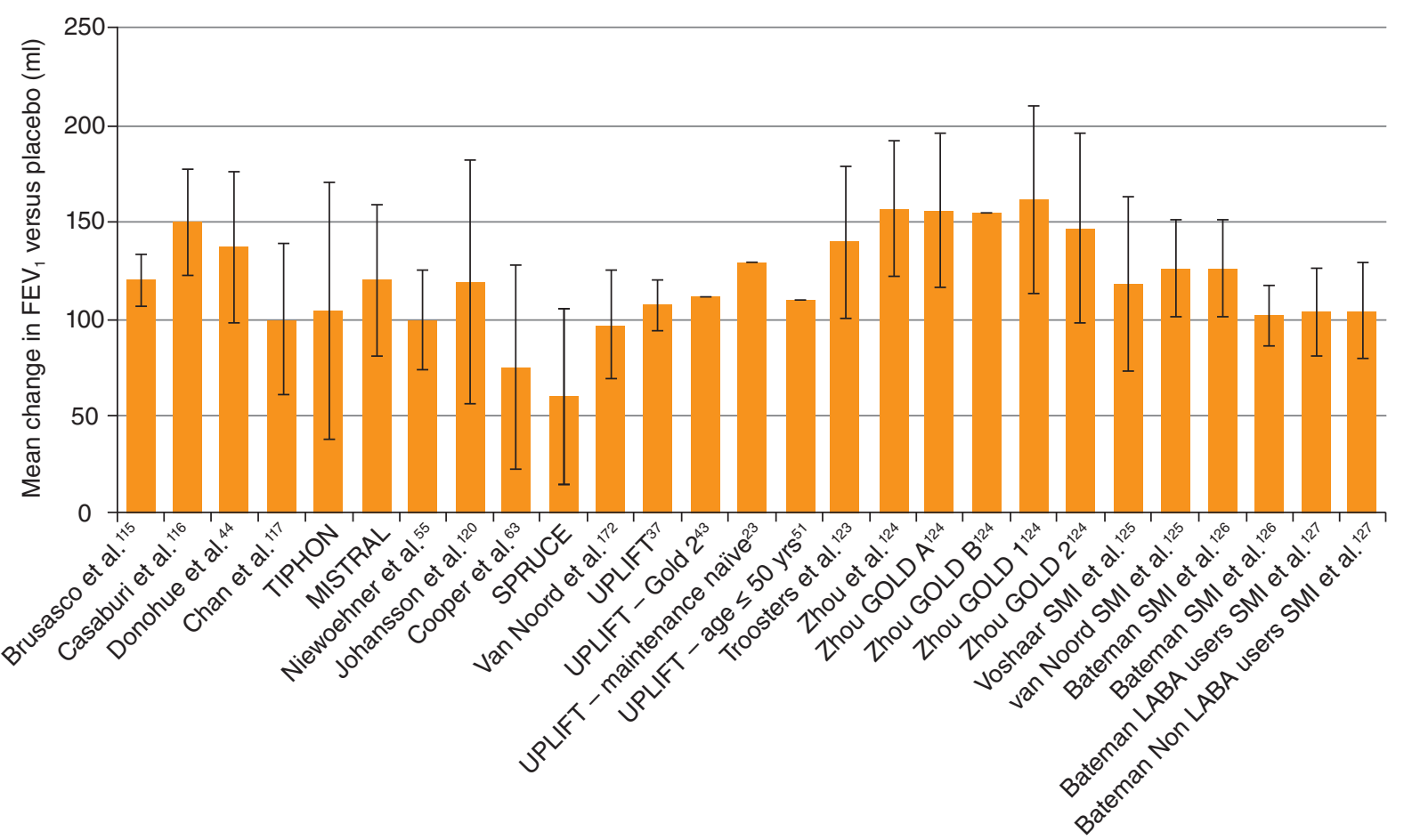

Figure 1. Mean effect of tiotropium on trough $\mathrm{FEV}_{1}( \pm 95 \% \mathrm{CI})$ compared to placebo across eighteen studies and subgroups within these studies. For details of the studies, including inclusion criteria and permitted medications see table 1.

$\mathrm{FEV}_{1}$ : forced expiratory volume in 1 second.

of the patients included, concomitant and prior use of maintenance therapy, age and whether the Handihaler or Respimat soft mist inhaler were used to deliver the tiotropium. The details of the studies are listed in table 1.

As well as the changes in spirometry, tiotropium produces sustained reductions of lung hyperinflation at rest and during exercise ${ }^{41}$ that lead to improvements in both exertional dyspnoea and exercise endurance as a result of the improved ability to increase tidal volume (Fig. 2).

Among the many trials examining the efficacy of tiotropium, the Understanding Potential Long-term Impacts on Function with Tiotropium (UPLIFT) study stands out as it studied the effects compared to placebo against a background of usual therapy including LABA and ICS in nearly six thousand patients over 4 years ${ }^{37}$. There were improvements in trough $\mathrm{FEV}_{1}$ when tiotropium was added of between 87 to $103 \mathrm{ml}$ pre-bronchodilator and between 47 to $65 \mathrm{ml}$ post-bronchodilator group and these improvements were maintained over four years. Improvements in $\mathrm{FEV}_{1}$ were observed across the spectrum of disease in GOLD Stages $2-4^{37}$ and GOLD 2011 Groups A-D COPD ${ }^{38}$ and were similar in current and ex-smokers ${ }^{42}$.

In the UPLIFT study the primary endpoint, the rate of decline in lung function, was not significantly different between patients treated with tiotropium and those receiving standard 
TABLE 1. Details of double blind studies examining the effect of tiotropium on trough forced expiratory volume in 1 second (FEV $)_{1}$ compared to placebo showing duration, basic inclusion criteria, other inhaled medication patients were allowed to use during the study, the percentage using these medications at randomisation and the estimated mean change in $\mathrm{FEV}_{1}$ and $95 \%$ confidence interval compared to placebo. (SMI - Respimat soft mist inhaler used to administer tiotropium)

\begin{tabular}{|c|c|c|c|c|}
\hline Study & Population & $\begin{array}{l}\text { Duration } \\
\text { (weeks) }\end{array}$ & $\begin{array}{c}\text { Background } \\
\text { therapy }\end{array}$ & $\begin{array}{c}\text { Mean } \Delta \text { trough FEV } \\
(95 \% \text { CI })(\mathrm{mL})\end{array}$ \\
\hline Brusasco et al. ${ }^{115}$ & $\begin{array}{l}\text { FEV } 1 \leq 65 \% \text { pred } \\
\text { FEV }_{1} / \mathrm{FVC} \leq 0.7\end{array}$ & 24 & & $120(106,133)$ \\
\hline Casaburi et al. ${ }^{116}$ & $\begin{array}{l}\mathrm{FEV}_{1} \leq 65 \% \text { pred } \\
\mathrm{FEV}_{1} / \mathrm{FVC} \leq 0.7\end{array}$ & 52 & ICS $(42 \%)$ & $150(123,177)$ \\
\hline Donohue et al. ${ }^{44}$ & $\begin{array}{l}\mathrm{FEV}_{1} \leq 60 \% \text { pred } \\
\mathrm{FEV}_{1} / \mathrm{FVC} \leq 0.7\end{array}$ & 24 & ICS $(66 \%)$ & $137(98,176)$ \\
\hline Chan et al. ${ }^{117}$ & $\begin{array}{l}\text { FEV } 1 \leq 65 \% \text { pred } \\
\text { FEV } 1 / F V C \leq 0.7 \\
\geq 1 \text { exac in last } 2 \mathrm{yr}\end{array}$ & 48 & $\begin{array}{l}\text { ICS }(68 \%) \\
\text { LABA }(53 \%)\end{array}$ & $100(61,139)$ \\
\hline TIPHON ${ }^{118}$ & $\begin{array}{l}\mathrm{FEV}_{1} 20-70 \% \text { pred } \\
\mathrm{FEV}_{1} / \mathrm{FVC} \leq 0.7\end{array}$ & 39 & ICS (33\%) & $104(37,170)$ \\
\hline MISTRAL ${ }^{119}$ & $\begin{array}{l}\mathrm{FEV}_{1} 30-65 \% \text { pred } \\
\mathrm{FEV}_{1} / \mathrm{FVC} \leq 0.7 \\
\geq 1 \text { exac in last yr }\end{array}$ & 52 & ICS (64\%) & $120(80,159)$ \\
\hline Niewoehner et al. ${ }^{55}$ & $\begin{array}{l}\mathrm{FEV}_{1} \leq 60 \% \text { pred } \\
\mathrm{FEV}_{1} / \mathrm{FVC} \leq 0.7\end{array}$ & 24 & $\begin{array}{l}\text { ICS }(60 \%) \\
\text { LABA }(38 \%)\end{array}$ & $100(75,125)$ \\
\hline Johansson et al. ${ }^{120}$ & $\begin{array}{l}\mathrm{FEV}_{1} \geq 60 \% \text { pred } \\
\mathrm{FEV}_{1} / \mathrm{FVC} \leq 0.7 \\
\mathrm{MRC} \geq 2\end{array}$ & 12 & none & $119(56,182)$ \\
\hline Cooper et al. ${ }^{63}$ & $\begin{array}{l}\mathrm{FEV}_{1} \leq 65 \% \text { pred } \\
\mathrm{FEV}_{1} / \mathrm{FVC} \leq 0.7 \\
\mathrm{MRC} \geq 2\end{array}$ & 96 & $\begin{array}{l}\text { ICS }(63 \%) \\
\text { LABA }(29 \%)\end{array}$ & $60(15,105)$ \\
\hline SPRUCE ${ }^{121}$ & $\begin{array}{l}\mathrm{FEV}_{1}, 30-65 \% \text { pred } \\
\mathrm{FEV}_{1} / \mathrm{FVC} \leq 0.7 \\
\text { No SAMA or LAMA in last year }\end{array}$ & & & \\
\hline van Noord et al. ${ }^{122}$ & $\begin{array}{l}\mathrm{FEV}_{1} \leq 60 \% \text { pred } \\
\mathrm{FEV}_{1} / \mathrm{FVC} \leq 0.7\end{array}$ & 30 & ICS (55\%) & $97(72,125)$ \\
\hline UPLIFT 37 & $\begin{array}{l}\mathrm{FEV}_{1} \leq 70 \% \text { pred } \\
\mathrm{FEV}_{1} / \mathrm{FVC} \leq 0.7\end{array}$ & 208 & $\begin{array}{l}\text { ICS }(74 \%) \\
\text { LABA }(72 \%)\end{array}$ & $107(93,120)$ \\
\hline UPLIFT - GOLD $2^{43}$ & $\begin{array}{l}\mathrm{FEV}_{1}, 50-70 \% \text { pred } \\
\mathrm{FEV}_{1} / \mathrm{FVC} \leq 0.7\end{array}$ & 208 & $\begin{array}{l}\text { ICS }(58 \%) \\
\text { LABA }(56 \%)\end{array}$ & 101 to 119 \\
\hline UPLIFT - maintenance naïve ${ }^{23}$ & $\begin{array}{l}\mathrm{FEV}_{1} \leq 70 \% \text { pred } \\
\mathrm{FEV}_{1} / \mathrm{FVC} \leq 0.7\end{array}$ & 208 & & 99 to 160 \\
\hline UPLIFT - age $\leq 50 \mathrm{yrs}^{51}$ & $\begin{array}{l}\mathrm{FEV}_{1} \leq 70 \% \text { pred } \\
\mathrm{FEV}_{1} / \mathrm{FVC} \leq 0.7\end{array}$ & 208 & $\begin{array}{l}\text { ICS }(58 \%) \\
\text { LABA }(57 \%)\end{array}$ & 82 to 148 \\
\hline Troosters et al. ${ }^{123}$ & $\begin{array}{l}\mathrm{FEV}_{1}, 50-80 \% \text { pred } \\
\mathrm{FEV}_{1} / \mathrm{FVC} \leq 0.7\end{array}$ & 24 & & $140(90,180)$ \\
\hline Zhou et al. ${ }^{124}$ & $\begin{array}{l}\mathrm{FEV}_{1}>50 \% \text { pred } \\
\mathrm{FEV}_{1} / \mathrm{FVC} \leq 0.7\end{array}$ & 104 & none & $157(123,192)$ \\
\hline Zhou et al. ${ }^{124}$ GOLD A & $\begin{array}{l}\mathrm{FEV}_{1}>50 \% \text { pred } \\
\mathrm{FEV}_{1} / \mathrm{FVC} \leq 0.7\end{array}$ & 104 & none & $156(116,196)$ \\
\hline Zhou et al. ${ }^{124}$ GOLD B & $\begin{array}{l}\mathrm{FEV}_{1}>50 \% \text { pred } \\
\mathrm{FEV}_{1} / \mathrm{FVC} \leq 0.7\end{array}$ & 104 & none & $155(85,224)$ \\
\hline Zhou et al. ${ }^{124}$ GOLD 1 & $\begin{array}{l}\mathrm{FEV}_{1}>80 \% \text { pred } \\
\mathrm{FEV}_{1} / \mathrm{FVC} \leq 0.7\end{array}$ & 104 & none & $162(115,210)$ \\
\hline Zhou et al. ${ }^{124}$ GOLD 2 & $\begin{array}{l}\mathrm{FEV}_{1}, 50-80 \% \text { pred } \\
\mathrm{FEV}_{1} / \mathrm{FVC} \leq 0.7\end{array}$ & 104 & none & $147(98,196)$ \\
\hline
\end{tabular}


TABLE 1. Continuation

\begin{tabular}{|c|c|c|c|c|}
\hline Study & Population & $\begin{array}{l}\text { Duration } \\
\text { (weeks) }\end{array}$ & $\begin{array}{c}\text { Background } \\
\text { therapy }\end{array}$ & $\begin{array}{l}\text { Mean } \Delta \text { trough FEV } \\
(95 \% \mathrm{CI})(\mathrm{mL})\end{array}$ \\
\hline Voshaar et al. ${ }^{125}$ SMI & $\begin{array}{l}\mathrm{FEV}_{1} \leq 60 \% \text { pred } \\
\mathrm{FEV}_{1} / \mathrm{FVC} \leq 0.7\end{array}$ & 12 & $\operatorname{ICS}(50 \%)$ & $118(73,163)$ \\
\hline van Noord et al. ${ }^{122}$ SMI & $\begin{array}{l}\mathrm{FEV}_{1} \leq 60 \% \text { pred } \\
\mathrm{FEV}_{1} / \mathrm{FVC} \leq 0.7\end{array}$ & 30 & $\operatorname{ICS}(55 \%)$ & $126(101,151)$ \\
\hline Bateman et al. ${ }^{126} \mathrm{SMI}$ & $\begin{array}{l}\mathrm{FEV}_{1} \leq 60 \% \text { pred } \\
\mathrm{FEV}_{1} / \mathrm{FVC} \leq 0.7\end{array}$ & 48 & $\operatorname{ICS}(52 \%)$ & $127(101,151)$ \\
\hline Bateman et al. ${ }^{127} \mathrm{SMI}$ & $\begin{array}{l}\mathrm{FEV}_{1} \leq 60 \% \text { pred } \\
\text { FEV }_{1} / \mathrm{FVC} \leq 0.7\end{array}$ & 48 & $\begin{array}{l}\text { ICS }(56 \%) \\
\text { LABA }(53 \%)\end{array}$ & $102(85,118)$ \\
\hline Bateman et al. ${ }^{127}$ LABA users SMI & $\begin{array}{l}\text { FEV }_{1} \leq 60 \% \text { pred } \\
\text { FEV }_{1} / \text { FVC } \leq 0.7\end{array}$ & 48 & $\begin{array}{l}\text { ICS }(90 \%) \\
\text { LABA }(100 \%)\end{array}$ & $104(82,127)$ \\
\hline Bateman et al. ${ }^{127}$ Non LABA users SMI & $\begin{array}{l}\mathrm{FEV}_{1} \leq 60 \% \text { pred } \\
\mathrm{FEV}_{1} / \mathrm{FVC} \leq 0.7\end{array}$ & 48 & ICS $(17 \%)$ & $101(74,129)$ \\
\hline
\end{tabular}

Cl: confidence interval; FEV : forced expiratory volume in 1 second; FVC: forced vital capacity; ICS: inhaled corticosteroids; LABA: Iong-acting beta ${ }_{2}$ agonists; LAMA: long-acting muscarinic antagonist; MRC: medical research council; pred: predicted; SAMA: short-acting muscarinic antagonists; SMI: soft mist inhaler. MISTRAL study: Mesure de I'Influence de Spiriva ${ }^{\circledR}$ sur les Troubles Respiratoires Aigus à Long terme. SPRUCE study: Efficacy and safety of tiotropium in COPD patients in primary care-the SPiRiva Usual CarE. TIPHON study: Effect of a 9-month treatment of SPIRIVA® on Health Related Quality of Life in patients with Chronic Obstructive Pulmonary Disease. Validation of a new HROoL questionnaire appropriate to common daily practice. UPLIFT study: Understanding potential long-term impacts on function with tiotropium study.
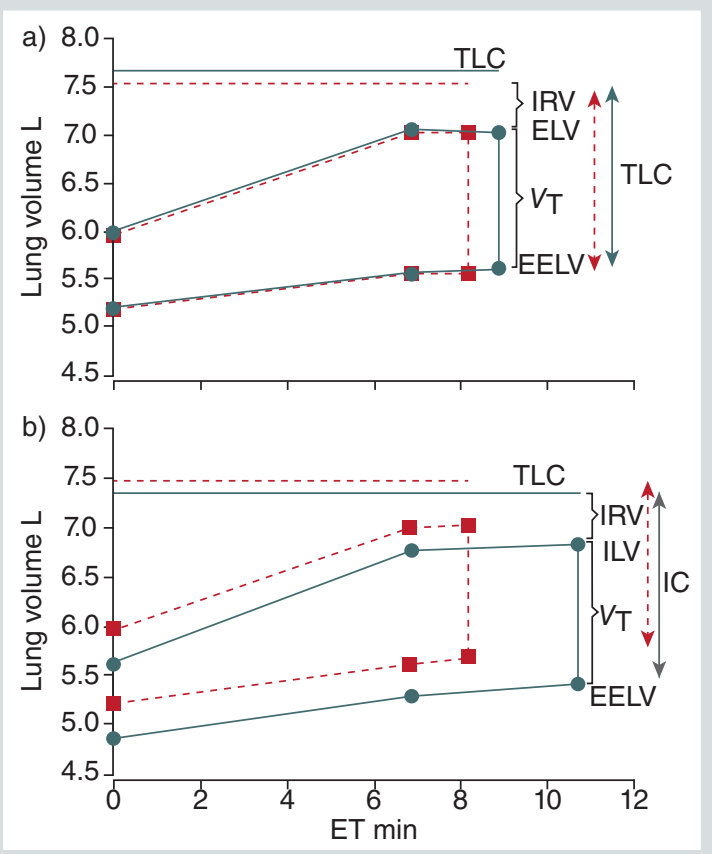

Figure 2. Operating lung volumes at rest and during exercise at baseline (- - ) and after 42 days (--) of treatment with placebo ( $\mathrm{a} ; \mathrm{n}=91$ ) and tiotropium (b; $\mathrm{n}=96$ ) (reproduced with permission from O'Donnell DE et al. ${ }^{41}$ under the Creative Commons Attribution Non-Commercial License).

EELV: end-expiratory lung volume; EILV: end-inspiratory lung volume; ET: endurance time; IC: inspiratory capacity; IRV: inspiratory reserve volume;; TLC: total lung capacity; $\mathrm{V}_{\mathrm{T}}$ : tidal volume. therapy in the whole population ${ }^{37}$; however, the rate of decline was significantly lower with tiotropium in patients with GOLD Stage 2 $\mathrm{COPD}^{43}$.

As well as trials comparing tiotropium to placebo there have been studies comparing tiotropium to other long acting bronchodilators. These have shown greater $\mathrm{FEV}_{1}$ improvements compared to twice-daily salmeterol ${ }^{44}$ and non-inferiority to once-daily indacaterol ${ }^{45}$. Comparisons versus other LAMAs in patients with moderate-to-severe COPD have generally shown similar effects on lung function ${ }^{46-48}$, although one study showed significantly greater improvements with umeclidinium versus tiotropium 12-24 hours post-dose ${ }^{49}$.

Tiotropium consistently improves symptoms and health status compared with placebo (for a comprehensive review of studies, see Kaplan et $\mathrm{al}^{50}$.) Figure 3 shows the effect of tiotropium on health status as measured using the St Georges Respiratory Questionnaire (SGRQ) compared 


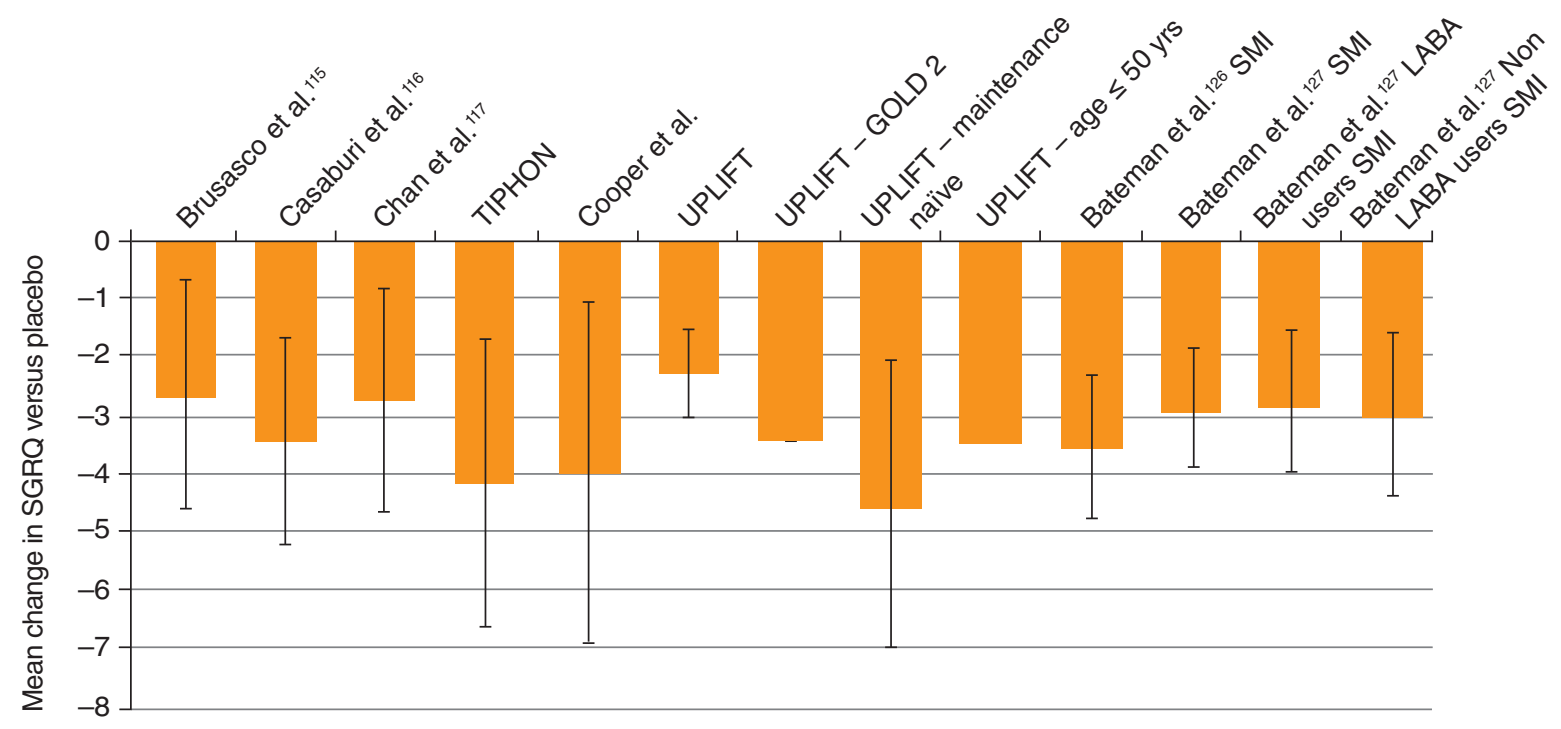

FigURE 3. Mean effect of tiotropium on St George's Respiratory Questionnaire (SGRO) ( $\pm 95 \%$ CI) compared to placebo. For details of the studies, including inclusion criteria and permitted medications see table 2.

SGRQ: St George's Respiratory Questionnaire.

with placebo across eight studies, which again varied in the severity of airflow obstruction and GOLD group of the patients included, concomitant and prior use of maintenance therapy, age and whether the Handihaler or Respimat soft mist inhaler were used to deliver the tiotropium. The details of the studies are listed in table 2. The magnitude of the mean effect is generally less than the 4 units considered the minimum clinically important difference, but the proportion of patients achieving a 4-unit change was significantly higher in all cases with tiotropium (Fig. 4 and Table 2).

In the UPLIFT study SGRQ was significantly improved by tiotropium compared with standard maintenance therapy on a background of standard care throughout the 4-year study period $^{37}$, including in GOLD 2 patients ${ }^{43}$, those who were naïve to maintenance therapy (i.e. not receiving LABA, ICS, theophyllines or anticholinergics) at baseline ${ }^{23}$ and those under the age of $50^{51}$.

Figure 5 shows the effect of tiotropium on breathlessness measured using the transitional dyspnoea index (TDI) compared to placebo in the four trials which have examined this. There is less heterogeneity in the characteristics and patients studied in these trials, although there is some variation in the concomitant and prior use of maintenance therapy and both the Handihaler or Respimat soft mist inhaler were used to deliver the tiotropium. The details of the studies are listed in table 3. In each case the magnitude of the mean effect reaches or exceeds the 1-unit change considered the minimum clinically important difference. 
TABLE 2. Details of double blind studies examining the effect of tiotropium on St George's Respiratory Questionnaire (SGRO) compared to placebo showing duration, basic inclusion criteria, other inhaled medication patients were allowed to use during the study, the percentage using these medications at randomisation, and the estimated mean change in SGRO and the odds ratio of having a 4-unit change with $95 \%$ confidence intervals compared to placebo (SMI - Respimat soft mist inhaler used to administer tiotropium)

\begin{tabular}{|c|c|c|c|c|c|}
\hline Study & Population & $\begin{array}{l}\text { Duration } \\
\text { (weeks) }\end{array}$ & $\begin{array}{l}\text { Background } \\
\text { therapy }\end{array}$ & $\begin{array}{l}\text { Mean } \Delta \text { SGRO } \\
\text { ( } 95 \% \text { CI) } \\
\text { from baseline }\end{array}$ & $\begin{array}{l}\text { Odds Ratio of achieving } \\
\text { a } 4 \text { unit change in SGRO } \\
\text { with tiotropium ( } 95 \% \text { CI) }\end{array}$ \\
\hline Brusasco et al. ${ }^{115}$ & $\begin{array}{l}\text { FEV }_{1} \leq 65 \% \text { pred } \\
\text { FEV }_{1} / \text { FVC } \leq 0.7\end{array}$ & 24 & & $\begin{array}{c}-2.70 \\
(-4.64,-0.76)\end{array}$ & $\begin{array}{c}1.48 \\
(1.09,2.00)\end{array}$ \\
\hline Casaburi et al. ${ }^{116}$ & $\begin{array}{l}\text { FEV }_{1} \leq 65 \% \text { pred } \\
\text { FEV }_{1} / \text { FVC } \leq 0.7\end{array}$ & 52 & $\operatorname{ICS}(42 \%)$ & $\begin{array}{c}-3.44 \\
(-5.24,-1.64)\end{array}$ & $\begin{array}{c}2.25 \\
(1.68,3.02)\end{array}$ \\
\hline Chan et al. ${ }^{117}$ & $\begin{array}{l}\mathrm{FEV}_{1} \leq 65 \% \text { pred } \\
\mathrm{FEV}_{1} / \mathrm{FVC} \leq 0.7 \\
\geq 1 \text { exac in last } 2 \mathrm{yr}\end{array}$ & 48 & $\begin{array}{l}\text { ICS }(68 \%) \\
\text { LABA }(53 \%)\end{array}$ & $\begin{array}{c}-2.79 \\
(-4.69,-0.89)\end{array}$ & $\begin{array}{c}1.43 \\
(1.05,1.95)\end{array}$ \\
\hline TIPHON ${ }^{118}$ & $\begin{array}{l}\text { FEV1 } 20-70 \% \text { pred } \\
\text { FEV }_{1} / \text { FVC } \leq 0.7\end{array}$ & 39 & ICS $(33 \%)$ & $\begin{array}{c}-4.18 \\
(-6.67,-1.69)\end{array}$ & $\begin{array}{c}1.56 \\
(1.09,2.22)\end{array}$ \\
\hline Cooper et al. ${ }^{63}$ & $\begin{array}{l}\mathrm{FEV}_{1} \leq 65 \% \text { pred } \\
\mathrm{FEV}_{1} / \mathrm{FVC} \leq 0.7 \\
\mathrm{MRC} \geq 2\end{array}$ & 96 & $\begin{array}{l}\text { ICS }(60 \%) \\
\text { LABA }(59 \%)\end{array}$ & $\begin{array}{c}-4.03 \\
(-6.97,-1.09)\end{array}$ & $\begin{array}{c}1.48 \\
(0.94,2.32)\end{array}$ \\
\hline UPLIFT ${ }^{37}$ & $\begin{array}{l}\text { FEV }_{1} \leq 70 \% \text { pred } \\
\text { FEV }_{1} / \text { FVC } \leq 0.7\end{array}$ & 208 & $\begin{array}{l}\text { ICS }(74 \%) \\
\text { LABA }(72 \%)\end{array}$ & $\begin{array}{c}-2.28 \\
(-3.02,-1.54)\end{array}$ & $\begin{array}{c}1.45 \\
(1.27,1.67)\end{array}$ \\
\hline UPLIFT - GOLD $2^{43}$ & $\begin{array}{l}\mathrm{FEV}_{1}, 50-70 \% \text { pred } \\
\mathrm{FEV}_{1} / \mathrm{FVC} \leq 0.7\end{array}$ & 208 & $\begin{array}{l}\text { ICS }(58 \%) \\
\text { LABA }(56 \%)\end{array}$ & -2.7 to -4.0 & $\mathrm{~N} / \mathrm{A}$ \\
\hline UPLIFT - maintenance naïve ${ }^{23}$ & $\begin{array}{l}\mathrm{FEV}_{1} \leq 70 \% \text { pred } \\
\mathrm{FEV}_{1} / \mathrm{FVC} \leq 0.7\end{array}$ & 208 & & $\begin{array}{c}-4.57 \\
(-7.06,-2.09)\end{array}$ & N/A \\
\hline UPLIFT - age $\leq 50 \mathrm{yrs}^{51}$ & $\begin{array}{l}\text { FEV }_{1} \leq 70 \% \text { pred } \\
\text { FEV }_{1} / \text { FVC } \leq 0.7\end{array}$ & 208 & $\begin{array}{l}\text { ICS }(58 \%) \\
\text { LABA }(57 \%)\end{array}$ & -3.0 to -4.1 & N/A \\
\hline Bateman et al. ${ }^{126}$ SMI & $\begin{array}{l}\text { FEV }_{1} \leq 60 \% \text { pred } \\
\text { FEV }_{1} / \text { FVC } \leq 0.7\end{array}$ & 48 & ICS (52\%) & $\begin{array}{c}-3.65 \\
(-4.81,-2.49)\end{array}$ & $\begin{array}{c}1.52 \\
(1.24,1.86)\end{array}$ \\
\hline Bateman et al. ${ }^{127}$ SMI & $\begin{array}{l}\text { FEV }_{1} \leq 60 \% \text { pred } \\
\text { FEV }_{1} / \text { FVC } \leq 0.7\end{array}$ & 48 & $\begin{array}{l}\text { ICS }(56 \%) \\
\text { LABA }(53 \%)\end{array}$ & $\begin{array}{c}-2.9 \\
(-3.9,-2.0)\end{array}$ & $\begin{array}{c}1.39 \\
(1.21,1.59)\end{array}$ \\
\hline $\begin{array}{l}\text { Bateman et al. }{ }^{127} \text { LABA users } \\
\text { SMI }\end{array}$ & $\begin{array}{l}\text { FEV }_{1} \leq 60 \% \text { pred } \\
\text { FEV }_{1} / \text { FVC } \leq 0.7\end{array}$ & 48 & $\begin{array}{l}\text { ICS }(90 \%) \\
\operatorname{LABA}(100 \%)\end{array}$ & $\begin{array}{c}-2.8 \\
(-4.0,-1.5)\end{array}$ & $\begin{array}{c}1.42 \\
(1.18,1.71)\end{array}$ \\
\hline $\begin{array}{l}\text { Bateman et al. }{ }^{127} \text { Non LABA } \\
\text { users SMI }\end{array}$ & $\begin{array}{l}\mathrm{FEV}_{1} \leq 60 \% \text { pred } \\
\mathrm{FEV}_{1} / \mathrm{FVC} \leq 0.7\end{array}$ & 48 & $\operatorname{ICS}(17 \%)$ & $\begin{array}{c}-3.0 \\
(-4.4,-1.5)\end{array}$ & $\begin{array}{c}1.36 \\
(1.11,1.66)\end{array}$ \\
\hline
\end{tabular}

$\mathrm{Cl}$ : confidence interval; exac: exacerbations; $\mathrm{FEV}_{1}$; forced expiratory volume in 1 second; FVC: forced vital capacity; ICS: inhaled corticosteroids; LABA: long-acting beta ${ }_{2}$ agonists; MRC: medical research council; pred: predicted; SGRO: St George's Respiratory Questionnaire; SMI: soft mist inhaler; yr: year.

As well as improving lung function and health status and reducing breathlessness, tiotropium reduces COPD exacerbation rates in patients with all disease severities and comorbid risk factors. The effects on all exacerbations and specifically on hospitalised exacerbations have been comprehensively reviewed ${ }^{29,52}$.

Overall tiotropium reduced the rate of exacerbations by between $14 \%$ and $52 \%$ depending on the population studied, what concomitant therapy was allowed and how exacerbations were recorded ${ }^{29}$. Evidence suggests that the effect is not simply due to sustained bronchodilation ${ }^{29}$. Potential mechanisms that may contribute to the preventive effects of tiotropium on COPD exacerbations are a reduction in the inflammatory stimulus repeated hyperinflation and deflation ${ }^{53}$, in a similar way to lung volume reduction surgery ${ }^{54}$, re-setting the threshold of 
TABLE 3. Details of double blind studies examining the effect of tiotropium on transitional dyspnoea index (TDI) compared to placebo showing duration, basic inclusion criteria, other inhaled medication patients were allowed to use during the study, the percentage using these medications at randomisation, and the estimated mean change in TDI with $95 \%$ confidence intervals compared with placebo (SMI - Respimat soft mist inhaler used to administer tiotropium)

\begin{tabular}{|c|c|c|c|c|}
\hline Study & Population & $\begin{array}{l}\text { Duration } \\
\text { (weeks) }\end{array}$ & $\begin{array}{c}\text { Background } \\
\text { therapy }\end{array}$ & $\begin{array}{l}\text { Mean } \Delta \text { TDI ( } 95 \% \text { CI) } \\
\text { from baseline }\end{array}$ \\
\hline Brusasco et al. ${ }^{115}$ & $\begin{array}{l}\mathrm{FEV}_{1} \leq 65 \% \text { pred } \\
\mathrm{FEV}_{1} / \mathrm{FVC} \leq 0.7\end{array}$ & 24 & & $1.1(0.5,1.7)$ \\
\hline Casaburi et al. ${ }^{116}$ & $\begin{array}{l}\mathrm{FEV}_{1} \leq 65 \% \text { pred } \\
\mathrm{FEV}_{1} / \mathrm{FVC} \leq 0.7\end{array}$ & 52 & ICS $(42 \%)$ & $1.0(0.4,1.6)$ \\
\hline Chan et al. ${ }^{117}$ & $\begin{array}{l}\mathrm{FEV}_{1} \leq 65 \% \text { pred } \\
\mathrm{FEV}_{1} / \mathrm{FVC} \leq 0.7 \\
\geq 1 \text { exac in last } 2 \mathrm{yr}\end{array}$ & 48 & $\begin{array}{l}\text { ICS }(68 \%) \\
\text { LABA }(53 \%)\end{array}$ & $1.0(0.4,1.6)$ \\
\hline Bateman et al. ${ }^{126}$ SMI & $\begin{array}{l}\mathrm{FEV}_{1} \leq 60 \% \text { pred } \\
\mathrm{FEV}_{1} / \mathrm{FVC} \leq 0.7\end{array}$ & 48 & $\operatorname{ICS}(52 \%)$ & $1.05(0.73,1.38)$ \\
\hline
\end{tabular}

CI: confidence interval; exac: exacerbations; ICS: inhaled corticosteroids; LABA: Iong-acting beta 2 agonists; pred: predicted; SGRQ: St George's Respiratory Questionnaire; SMI: soft mist inhaler; TDI: transitional dyspnoea index; yr: year.

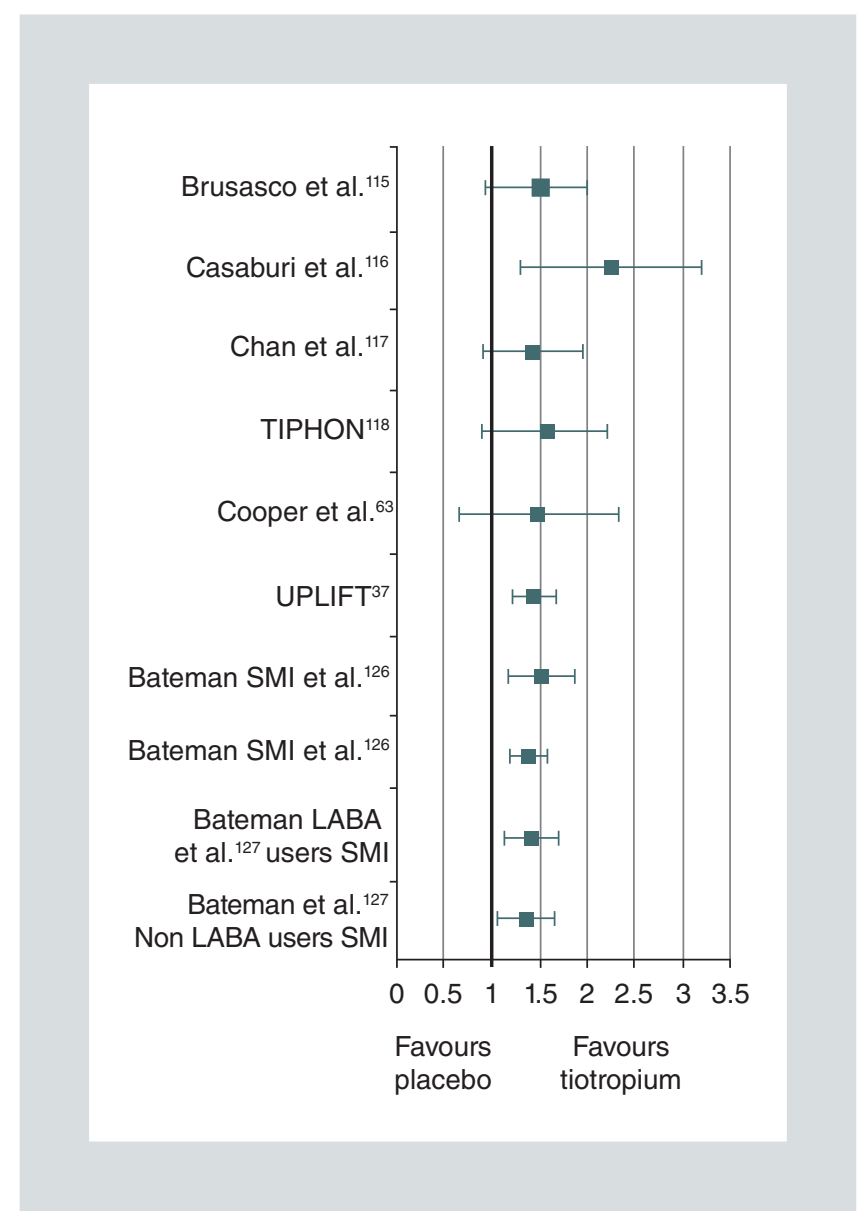

FiguRE 4. Odds ratio for patients achieving a 4-unit improvement in St George's Respiratory Questionnaire (SGRO) ( $\pm 95 \% \mathrm{CI}$ ) with tiotropium compared to placebo. For details of the studies, including inclusion criteria and permitted medications see table 2. SGRO: St George's Respiratory Questionnaire.

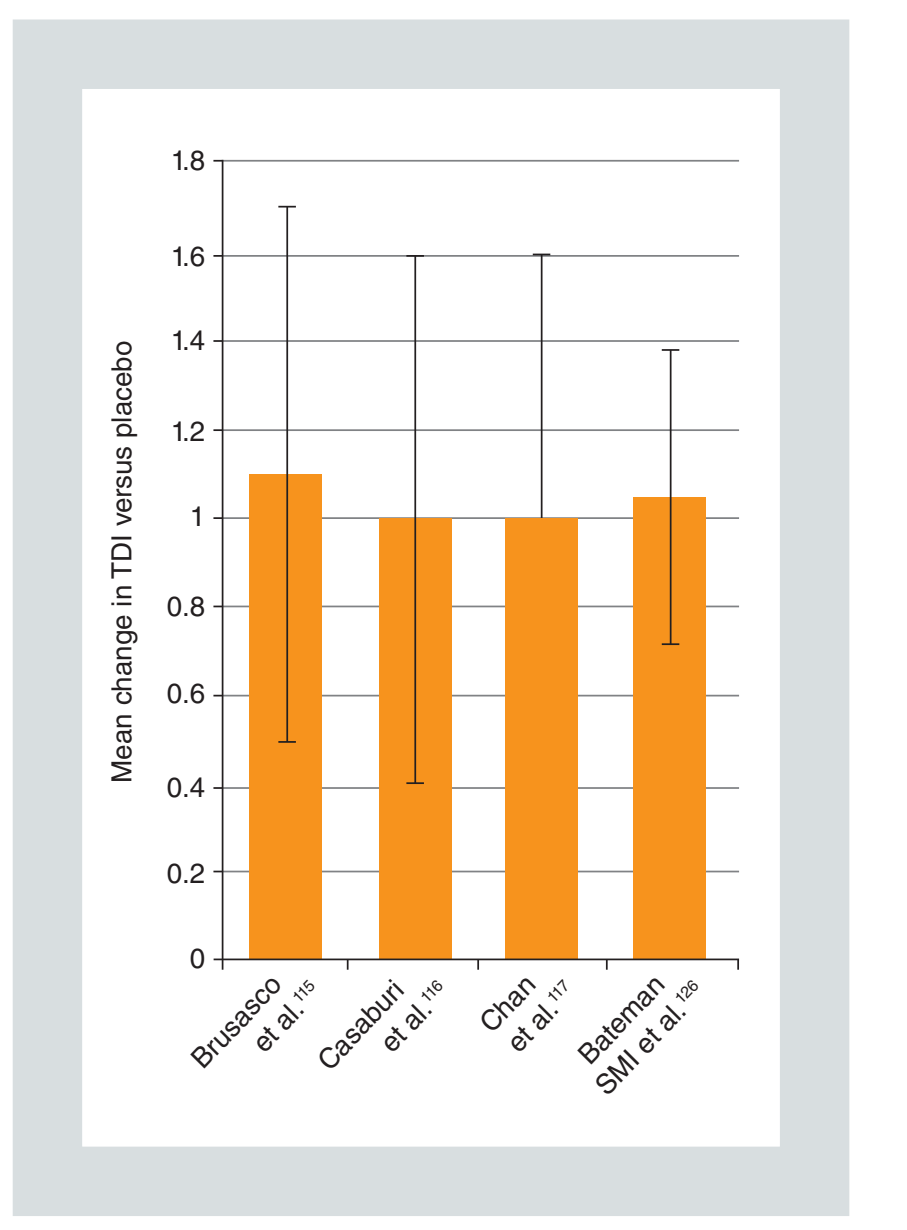

Figure 5. Mean effect of tiotropium on transitional dyspnoea index (TDI) $( \pm 95 \% \mathrm{CI}$ ) compared to placebo. For details of the studies, including inclusion criteria and permitted medications see table 3 .

TDI: transitional dyspnoea index. 
lung function/dynamics (end-expiratory lung volume [EELV] and residual volume) at which an exacerbation is triggered, reduction of mucus secretion $^{55}$ and suppression of acetylcholine-mediated inflammatory responses ${ }^{56}$.

In UPLIFT, tiotropium significantly delayed time to first exacerbation and first severe (hospitalised) exacerbation and reduced the number of exacerbations by $14 \%$ over 4 years versus standard respiratory therapy $(\mathrm{p}<0.001)^{37}$. In a post-hoc analysis exacerbation risk was reduced with tiotropium across all GOLD stages ${ }^{38}$.

Studies have shown that tiotropium is significantly more effective at reducing exacerbations than either once or twice daily LABAs $29,45,57,58$. The Investigation New Standards For Prophylaxis In Reduction Of Exacerbations (INSPIRE) study showed tiotropium had a similar effect on exacerbation rate to salmeterol/fluticasone, but patients treated with salmeterol/fluticasone had an increased incidence of pneumonia ( $8 \%$ versus $4 \%$ with tiotropium; $\mathrm{p}=0.008)^{59}$.

The effect of tiotropium on exacerbations is similar whether the Respimat or HandiHaler devices are used ${ }^{40}$ and the reduction in exacerbations provided by tiotropium may additionally have beneficial effects on cardiovascular disease and mortality as well as on COPD itself ${ }^{60}$.

The effects of tiotropium on lung function lead to an improvement in exercise capacity endurance, particularly when combined with pulmonary rehabilitation ${ }^{4,61-64}$.

Glycopyrronium bromide, aclidinium and umeclidinium are also LAMAs licensed for once or twice daily use in COPD. They each have data showing effects on lung function, health status, breathlessness and exacerbations compared to placebo $^{65,66}$.

The efficacy of twice-daily (bid) aclidinium bromide has been examined in 12 placebo randomised controlled trials lasting between 4 and 52 weeks. In a meta-analysis of these studies, aclidinium resulted in a significantly greater improvement in pre-dose $\mathrm{FEV}_{1}$ than placebo with a mean difference of $0.10 \mathrm{~L}$ ( $95 \%$ confidence interval [CI]: 0.08, 0.10), an improvement in TDI compared with placebo of 0.72 (95\% CI: 0.33, 1.11), and an improvement in SGRQ total score compared to placebo of -2.51 (95\% CI: -3.50 to -1.51$)^{67}$. There was no significant difference between the number of patients treated with aclidinium and placebo having an exacerbation (odds ratio [OR] 0.83, 95\% CI: 0.66, 1.05).

Studies have examined the effects of two doses of umeclidinium (62.5 $\mu$ g [the licensed dose] and $125 \mu \mathrm{g}$ ), but the results have been pooled when meta-analysed ${ }^{68}$. Umeclidinium produced an overall mean improvement in trough $\mathrm{FEV}_{1}$ of $0.13 \mathrm{~L}(95 \%$ CI: $0.11,0.14)$ compared to placebo and no significant difference compared to tiotropium (0.04L 95\% CI: $-0.01,0.09)$. TDI was improved by 0.63 (95\% CI: $0.27,0.99)$ by umeclidinium compared to placebo but the mean effect was smaller, although not significantly different, compared to tiotropium $(-0.20$ $95 \%$ CI: $-0.75,0.35)$. There is considerable heterogeneity in the effect of umeclidinium on health status measured by SGRQ compared to placebo, with 3 studies showing no effect, but an overall mean change of -2.15 (95\% CI: -4.11 , -0.18 ) and a less, but non-significantly different, effect compared to tiotropium (mean difference 1.38 [95\% CI: -1.28, 4.04]). Umeclidinium delayed the time to first exacerbation compared to placebo (hazard ratio [HR] 0.53 (95\% CI: 0.40, 
0.70), but there are no direct comparisons of the effect of umeclidinium and tiotropium on exacerbations.

A meta-analysis of the Glycopyrronium Bromide in COPD AirWays (GLOW)1, GLOW2 and the Dual bronchodilation with QVA149 versus single bronchodilator therapy (SHINE) studies has examined the effect of glycopyrronium $50 \mu \mathrm{g}$ once daily compared to placebo after 24 weeks. The GLOW 2 study is the only randomised trial to examine effects over 52 weeks. After 24 weeks glycopyrronium produced a mean improvement in the pooled studies in $\mathrm{FEV}_{1}$ of $0.135 \mathrm{~L}$ (95\%: CI $\left.-0.123,0.138\right)^{30}$. At 52 weeks in GLOW2 the mean improvement was $0.108 \mathrm{~L}$ (95\% CI: 0.070, 0.146). Compared to placebo after 24 weeks glycopyrronium significantly improved TDI by 1.01 (95\% CI: 0.79, 1.22) and SGRQ by -3.14 (95\% CI: $-3.83,-2.45)^{30}$. The GLOW5 trial, a 12-week blinded, double-dummy study comparing glycopyrronium with tiotropium, showed no difference between the two LAMAs in their effect on trough $\mathrm{FEV}_{1}$, TDI and SGRQ ${ }^{48}$. The study was too short to examine any difference in the effect on exacerbations.

Despite the effectiveness of tiotropium and other LAMAs, a significant proportion of patients remain breathless despite treatment with long-acting bronchodilator monotherapy ${ }^{69}$. GOLD recommends that for such patients, therapy should be escalated to dual therapy using two bronchodilators with different mechanisms of action ${ }^{3}$. For such patients, tiotropium is now available in combination with the new LABA olodaterol in the Respimat and a large phase III clinical trial programme of over 8000 patients ${ }^{70,71}$ has shown significant improvements in lung function compared to monotherapy ${ }^{72}$, irrespective of whether patients received prior LAMA or LABA maintenance treatment ${ }^{73-75}$. Other effects of the combination include reduced breathlessness and reduced rescue medication, as well as improvement in quality of life and exercise endurance ${ }^{73,75}$, with the combination having a similar safety profile similar to the monotherapy components ${ }^{73}$.

Dual bronchodilator therapy is recommended by GOLD as the preferred choice for patients in Group D (i.e. higher levels of symptoms and higher risk of exacerbations) $)^{3}$. Escalation to triple therapy with LABA, LAMA and ICS is recommended if patients continue to exacerbate, but de-escalation by withdrawing ICS from triple therapy is also recommended as dual bronchodilator therapy can be as effective as triple therapy in preventing exacerbations. The Withdrawal Of Inhaled Glucocorticoids And Exacerbations of COPD (WISDOM) trial showed that withdrawal of the fluticasone in three steps over a 12-week period from triple therapy consisting of tiotropium (18 $\mu$ g once daily), salmeterol (50 $\mu \mathrm{g}$ twice daily), and fluticasone propionate (500 $\mu \mathrm{g}$ twice daily) did not result in an increase rate of exacerbations ${ }^{76}$. Withdrawal of fluticasone did lead to a mean fall in $\mathrm{FEV}_{1}$ of $38 \mathrm{ml}$ after 18 weeks and $43 \mathrm{ml}$ after 52 weeks, but there was no significant effect on modified Medical Research Council dyspnoea (mMRC) scores. There was an increased SGRQ score (i.e. worsening) of 0.55 points in the glucocorticoid-withdrawal group and a reduction of 0.42 points in the glucocorticoid-continuation group at week $27(p=0.08)$ and an increase of 1.15 and a decrease of 0.07 , respectively, at week $52(\mathrm{p}=0.047)$. The patients studied had an $\mathrm{FEV}_{1}$ $<50 \%$ predicted and had had at least one exacerbation in the previous 12 months; they were all treated with triple therapy for 6 weeks 
before the ICS withdrawal began, but only 39\% of them had been on triple therapy prior to enrolment. In total $47 \%$ had been on a LAMA, $65 \%$ on a LABA and $70 \%$ on an ICS. In this population, dual bronchodilator therapy with tiotropium and salmeterol facilitated ICS withdrawal without increasing the risk of exacerbations, but a key question is whether there are sub-groups of patients who do better if maintained on ICS. A post hoc analysis of the WISDOM study has shown that patients with a history of two or more exacerbations per year plus an eosinophil count $\geq 300$ cells $/ \mathrm{ml}$ have a lower risk of exacerbation if continued on ICS ${ }^{77}$.

\section{CLINICAL EFFECTS OF TIOTROPIUM IN ASTHMA}

Despite major advances in the management of asthma many patients, including children and adolescents remain uncontrolled and remain at risk of exacerbations ${ }^{78-80}$. LABA/ICS can achieve well-controlled asthma in around $70 \%$ of patients but not all ${ }^{81}$. Anticholinergic bronchodilators are the oldest documented therapy for asthma ${ }^{82}$.

The effects of tiotropium in asthma were first explored over 20 years ago when the sustained bronchodilator effects and protective effects against methacholine challenge were shown ${ }^{83}$. More recently, the National Heart, Lung, and Blood Institute Asthma Clinical Research Network (ACRN) in the United States (US) undertook a study to investigate the effects of adding tiotropium to an inhaled glucocorticoid, compared to doubling of the dose of the inhaled glucocorticoid or adding the LABA salmeter$\mathrm{ol}^{84}$. Tiotropium improved lung function by $0.10 \mathrm{~L}(95 \% \mathrm{CI}: 0.03,0.17)$ and symptom control measured by the asthma control questionnaire (ACQ) by -0.18 (95\% CI: $-0.34,-0.03)$ compared with doubling the ICS dose and increased the pre-bronchodilator $\mathrm{FEV}_{1}$ more than salmeterol (mean difference 0.11L [95\% CI: 0.04 to 0.18]).

The effects of tiotropium administered via the Respimat in asthma have now been studied in an extensive clinical trial programme including over 6000 patients, including children, adolescents and adults with uncontrolled mild to moderate and severe asthma ${ }^{85-98}$. The findings supported of the individual studies have been supported by systematic reviews and meta-analyses $^{99-101}$. The addition of tiotropium to ICS only, or ICS plus LABA results in statistically and clinically significant improvements in lung function, clinically significant reductions in exacerbation risk and improved asthma control ${ }^{102}$.

In the two PrimoTinA-asthma studies $5 \mu \mathrm{g}$ tiotropium administered via the Respimat was added to therapy with LABA and ICS $(\geq 800 \mu \mathrm{g}$ of budesonide or the equivalent) in people with uncontrolled asthma (ACQ $\geq 1.5)^{90}$. Two of the co-primary end points were changes in peak $\mathrm{FEV}_{1}$ (within 3 hours of administration) and trough $\mathrm{FEV}_{1}$ at 24 weeks. Tiotropium resulted in an increase in peak $\mathrm{FEV}_{1}(0-3 \mathrm{~h})$ of $86 \mathrm{ml}(95 \%$ CI: 20, 152) in trial 1 and $154 \mathrm{ml}(95 \%$ CI: 91, 217) in trial 2 and an increase in trough $\mathrm{FEV}_{1}$ of $88 \mathrm{ml}$ (95\% CI: 27, 149) in trial 1 and $111 \mathrm{ml}$ (95\% CI: 53, 169) in trial 2. In a pre-specified pooled analysis of the two trials there was a $21 \%$ reduction in the risk of having an exacerbation in patients treated with tiotropium (HR, 0.79, 95\% CI: 0.62, 1.00). This was the third co-primary end point.

After 48 weeks tiotropium resulted in an increase in peak $\mathrm{FEV}_{1}(0-3 \mathrm{~h})$ of $73 \mathrm{ml}(95 \% \mathrm{CI}$ : $5,140)$ in trial 1 and $152 \mathrm{ml}(95 \% \mathrm{CI}: 87,217)$ 
in trial 2. The changes in trough $\mathrm{FEV}_{1}$ after 48 weeks were $42 \mathrm{ml}$ (95\% CI: -21, 104) in trial 1 and $92 \mathrm{ml}(95 \% \mathrm{CI}: 32,151)$ in trial 2. Improvements in asthma control and quality of life were also observed in both trials with marked improvements in the placebo groups particularly in trial 1. At week 24, the mean difference in ACQ-7 scores and Asthma Quality Of Life Questionnaire (AQLQ) score between groups was only statistically significant in trial 2 but did not exceed the minimal clinically important differences for the ACQ-7 of 0.5 or AQLQ of 0.5.

Pre-specified post hoc subgroup analyses of the PrimoTinA-asthma trials showed that the improvements in peak $\mathrm{FEV}_{1}$ with tiotropium tended to be larger in patients with a lower $\mathrm{FEV}_{1}$ and in ex-smokers, but were not related to level of reversibility, age, body-mass index, allergic status, asthma duration, ACQ-7 score at baseline, or prior use of systemic glucocorticoids ${ }^{103}$.

A further two replicated, double-dummy trials, the MezzoTinA-asthma studies have examined the effects of tiotropium in patients with moderate symptomatic asthma (ACQ-7 score $\geq 1.5$ ) and persistent airflow obstruction (post-bronchodilator $\mathrm{FEV}_{1}, 60-90 \%$ ) despite treatment with medium-dose ICS (400-800 $\mu \mathrm{g}$ of budesonide or the equivalent $)^{91}$. Patients received once-daily tiotropium 5 or $2.5 \mu$ g, twice-daily salmeterol $50 \mu \mathrm{g}$, or matching placebo for 24 weeks. Tiotropium significantly improved pooled peak $\mathrm{FEV}_{1}$ by $185 \mathrm{ml}(95 \% \mathrm{CI}: 146,223)$ with $5 \mu \mathrm{g}$ and $223 \mathrm{ml}(95 \%$ CI: 185, 262) with $2.5 \mu \mathrm{g}$. The improvements in peak $\mathrm{FEV}_{1}$ were maintained over 24 hours. Both doses also led to significant improvements in asthma control, as assessed by ACQ-7 responder rate: OR, 1.32 (95\% CI: 1.02, 1.71) for $5 \mu \mathrm{g}$ and 1.33 (95\% CI: 1.03, 1.72) for $2.5 \mu \mathrm{g}$. The effects of tiotropium were similar to those of salmeterol, which increased peak $\mathrm{FEV}_{1}$ by $196 \mathrm{ml}$ (95\% CI: 158, 234) and increased the proportion showing an ACQ response (OR: 1.46; $95 \%$ CI: $1.13,1.89$ ), while $5 \mu \mathrm{g}$ tiotropium prolonged the time to the first severe asthma exacerbation (HR 0.72 [95\% CI: 0.45, 1.14]) but this was not statistically significant, possibly reflecting the low rate of exacerbations in these patients.

The Grazzia-TinA-asthma trial examined the effect of tiotropium in adults with symptomatic asthma (ACQ-7 score $\geq 1.5$ ) and persistent airflow obstruction (post-bronchodilator $\mathrm{FEV}_{1}$

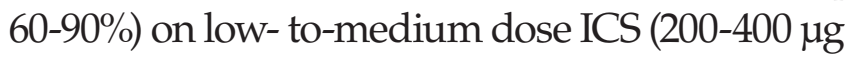
of budesonide or the equivalent) therapy ${ }^{92}$. Both $2.5 \mu \mathrm{g}$ and $5 \mu \mathrm{g}$ of tiotropium improved peak $\mathrm{FEV}_{1}(0-3 \mathrm{~h})$ compared to placebo (adjusted mean difference $128 \mathrm{ml}(95 \% \mathrm{CI}: 57,199)$ for $5 \mu \mathrm{g}$; $159 \mathrm{ml}(95 \% \mathrm{CI}: 88,230)$ for $2.5 \mu \mathrm{g}$. Both doses also improved the secondary endpoints of trough $\mathrm{FEV}_{1}$ and $\mathrm{FEV}_{1}$ area under the curve (0-3h), and morning and evening PEF compared to placebo.

A post-hoc analysis of the PrimoTinA-asthma and MezzoTinA-asthma studies has examined whether the coprimary endpoints were influenced by serum immunoglobulin E (IgE) levels, blood eosinophil counts, or clinician judgment of allergic asthma. In addition, the influence of the continuous parameters of $\operatorname{IgE}$ and blood eosinophils was modelled over the whole range of values ${ }^{104}$. Tiotropium was found to be efficacious in improving peak and trough $\mathrm{FEV}_{1}$ and reducing the risk of severe asthma exacerbations and asthma worsening, independent of T2 status. The effect of tiotropium on exacerbations was independent of IgE levels or eosinophil counts when analysed continuously and numerical improvements the ACQ responder 
rate were observed in both $\mathrm{T} 2_{\text {high }}$ and $\mathrm{T} 2_{\text {low }}$ patients.

An observational study of patients with asthma treated in primary care in the United Kingdom (UK) has also shown tiotropium leads to a reduction in the percentage of patients having at least one exacerbation from $37 \%$ to $27 \%$ after 1 year ${ }^{105}$. Tiotropium has been shown to be a cost-effective approach to asthma care, principally as a result of the reduced expenditure on exacerbations and improved quality of life ${ }^{106}$ and the Global Initiative for Asthma (GINA) guidelines now recommend tiotropium as an add-on therapy for Steps 4 and 5 of the treatment pathway, independent of patient phenotype ${ }^{107}$.

Overall in adults seven trials have assessed the effect of $5 \mu \mathrm{g}$ of tiotropium and four the effect of $2.5 \mu \mathrm{g}$ as add on therapy to at least ICS in asthma. For some outcomes in some studies $5 \mu \mathrm{g}$ was not superior to $2.5 \mu \mathrm{g}$, but taking all outcomes into account, including morning and evening peak flow results and the safety data (see below), the European Medicines Agency (EMA) and other regulators decided that $5 \mu \mathrm{g}$ should be the recommended dose. However, in the US the Food and Drug Administration (FDA) took a different view, perhaps reflecting their caution regarding the dose of inhaled long-acting bronchodilators and decided that $2.5 \mu \mathrm{g}$ should be the recommended dose.

\section{SAFETY OF TIOTROPIUM IN COPD AND ASTHMA}

When delivered via Respimat $5 \mu \mathrm{g}$, approximately $40 \%$ of the inhaled dose of tiotropium reaches the lungs and 33\% reaches systemic circulation $^{108}$; similar systemic exposures and urinary excretion levels are seen with HandiHaler ${ }^{109,110}$. Gastrointestinal absorption of LAMAs is low and the structure of tiotropium also prevents crossing of the blood-brain barrier, avoiding the risk of central neurologic effects ${ }^{111}$.

The safety profile of tiotropium in people with COPD using both the HandiHaler and the Respimat has been well characterised. In patients across all disease severities and with a range of common comorbidities there is a low incidence of adverse events ${ }^{36}$. Dry mouth is a predictable but relatively infrequent side effect of anticholinergics: in a meta-analysis of 16 trials the cumulative incidence of dry mouth with tiotropium was $7.4 \%$, compared with $3.9 \%$ with ipratropium, $1.6 \%$ with salmeterol and $2.0 \%$ with placebo $^{33}$.

Pooled analyses of clinical trials of tiotropium have shown reduced rates of cardiac adverse events and cardiovascular mortality versus placebo $^{36,60}$. Long-term data from UPLIFT demonstrated no increase in all-cause and cardiovascular mortality, nor any increased risk of myocardial infarction or stroke versus standard care $^{37}$. In fact, there was a reduction in cardiac adverse events in people treated with tiotropi$\mathrm{um}^{112}$. The Tiotropium Safety and Performance in Respimat (TIOSPIR) study also demonstrated conclusively that there was no difference in the cardiac or other safety signal between tiotropium HandiHaler and tiotropium Respimat ${ }^{40}$ in people with COPD.

In line with previous studies, a recent study in Taiwan has shown that patients with COPD who are established on long acting bronchodilator therapy (both LABA and LAMA) are at a reduced risk of cardiovascular disease, 
but it has suggested that for the first 30 days after initiation of long acting bronchodilator therapy patients may be at an increased risk ${ }^{113}$. This needs to be examined in other cohorts.

The safety of tiotropium in asthma has been evaluated in more than 6,000 patients as addon to ICS and ICS plus LABA, with treatment durations up to 1 year. In studies of patients with uncontrolled severe asthma including 912 patients, the incidence of adverse events was similar in the tiotropium and placebo groups and no deaths were reported ${ }^{114}$.

\section{SUMMARY}

Tiotropium is an effective inhaled anti-muscarinic which improves lung function and patient reported outcomes, including health status, and reduces exacerbations in people with COPD, as well as slowing disease progression in those with GOLD grade 2 disease. In children, adolescents and adults with asthma it improves lung function and control when added to at least ICS therapy. There is no evidence of any significant adverse effects and in particular there are no cardiovascular safety concerns. It is a very important and effective therapy for people with chronic obstructive airways diseases.

\section{CONFLICT OF INTEREST}

Dr. David Halpin reports personal fees from AstraZeneca, personal fees and non-financial support from Boehringer Ingelheim, personal fees from GlaxoSmithKline, personal fees and non-financial support from Novartis, personal fees from Pfizer, personal fees from Chiesi, outside the submitted work.

\section{REFERENCES}

1. Institute for Health Metrics and Evaluation (IHME). GBD Compare Data Visualization. Seattle, WA: IHME, University of Washington. 2017. Available from: https://vizhub.healthdata.org/gbd-compare/.

2. GBD 2015 Chronic Respiratory Disease Collaborators. Global, regional, and national deaths, prevalence, disability-adjusted life years, and years lived with disability for chronic obstructive pulmonary disease and asthma, 1990-2015: a systematic analysis for the Global Burden of Disease Study 2015. Lancet Respir Med. 2017;5:691-706.

3. Vogelmeier CF, Criner GJ, Martinez FJ et al. Global Strategy for the Diagnosis, Management, and Prevention of Chronic Obstructive Lung Disease 2017 Report: GOLD Executive Summary. Eur Respir J. 2017;49: pii:1750214.

4. Global Initiative for Asthma. Global strategy for asthma management and prevention. (updated 2015) 2016. Available from: http://www.ginasthma.org.

5. Yohannes AM, Connolly MJ, Hanania NA. Ten years of tiotropium: clinical impact and patient perspectives. Int J Chron Obstruct Pulmon Dis. 2013;8: 17-25.

6. Proskocil BJ, Sekhon HS, Jia Y et al. Acetylcholine is an autocrine or paracrine hormone synthesized and secreted by airway bronchial epithelial cells. Endocrinology. 2004;145:2498-506.

7. Kistemaker LE, Gosens R. Acetylcholine beyond bronchoconstriction: roles in inflammation and remodeling. Trends Pharmacol Sci. 2015;36:164-71.

8. Gwilt CR, Donnelly LE, Rogers DF. The non-neuronal cholinergic system in the airways: an unappreciated regulatory role in pulmonary inflammation? Pharmacol Ther. 2007;115:208-22.

9. Gosens R, Zaagsma J, Meurs H, Halayko AJ. Muscarinic receptor signaling in the pathophysiology of asthma and COPD. Respir Res. 2006;7:73.

10. Grando SA, Kawashima K, Kirkpatrick CJ, Meurs H, Wessler I. The non-neuronal cholinergic system: basic science, therapeutic implications and new perspectives. Life Sci. 2012;91:969-72.

11. Disse B, Speck GA, Rominger KL, Witek TJ, Jr., Hammer R. Tiotropium (Spiriva): mechanistical considerations and clinical profile in obstructive lung disease. Life Sci. 1999;64:457-64.

12. Bateman ED, Rennard S, Barnes PJ et al. Alternative mechanisms for tiotropium. Pulm Pharmacol Ther. 2009; 22:533-42.

13. Bos IS, Gosens R, Zuidhof AB et al. Inhibition of allergen-induced airway remodelling by tiotropium and budesonide: a comparison. Eur Respir J. 2007;30:653-61

14. Powrie DJ, Wilkinson TM, Donaldson GC et al. Effect of tiotropium on sputum and serum inflammatory markers and exacerbations in COPD. Eur Respir J. 2007;30:472-8.

15. Ichinose M. Differences of inflammatory mechanisms in asthma and COPD Allergol Int. 2009;58:307-13.

16. Gosens R, Bos IS, Zaagsma J, Meurs H. Protective effects of tiotropium bromide in the progression of airway smooth muscle remodeling. Am J Respir Crit Care Med. 2005;171:1096-102.

17. Wollin L, Pieper MP. Tiotropium bromide exerts anti-inflammatory activity in a cigarette smoke mouse model of COPD. Pulm Pharmacol Ther. 2010;23 345-54.

18. Ohta S, Oda N, Yokoe $\mathrm{T}$ et al. Effect of tiotropium bromide on airway inflammation and remodelling in a mouse model of asthma. Clin Exp Allergy. 2010;40:1266-75.

19. Halpin DM, Kaplan AG, Russell RK. Why choose tiotropium for my patient? A comprehensive review of actions and outcomes versus other bronchodilators. Respir Med. 2017;128:28-41.

20. Keating GM. Tiotropium $\operatorname{Respimat}((\mathrm{R}))$ Soft Mist inhaler: a review of its use in chronic obstructive pulmonary disease. Drugs. 2014;74:1801-16.

21. Halpin DM, Kerkhof M, Soriano JB, Mikkelsen H, Price DB. Eligibility of real-life patients with COPD for inclusion in trials of inhaled long-acting bronchodilator therapy. Respir Res. 2016;17:120. 
22. Miravitlles M, Price D, Rabe KF, Schmidt H, Metzdorf N, Celli B. Comorbidities of patients in tiotropium clinical trials: comparison with observational studies of patients with chronic obstructive pulmonary disease. Int J Chron Obstruct Pulmon Dis. 2015;10:549-64.

23. Troosters T, Celli B, Lystig T et al. Tiotropium as a first maintenance drug in COPD: secondary analysis of the UPLIFT trial. Eur Respir J. 2010; 36:65-73.

24. Wise R, Calverley PM, Dahl R et al. Safety and efficacy of tiotropium Respimat versus HandiHaler in patients naive to treatment with inhaled anticholinergics: a post hoc analysis of the TIOSPIR trial. NPJ Prim Care Respir Med. 2015;25:15067.

25. Tashkin DP, Leimer I, Metzdorf N, Decramer M. Cardiac safety of tiotropium in patients with cardiac events: a retrospective analysis of the UPLIFT(R) trial. Respir Res. 2015;16:65.

26. Wise R, Fowler A, Metzdorf N, Dewberry H, Mueller A, Kowey PR. Safety of tiotropium in patients with cardiac events in the TIOSPIR® trial. Eur Respir J. 2015;46; PA985

27. Wise RA, Anzueto A, Calverley P et al. The Tiotropium Safety and Performance in Respimat Trial (TIOSPIR), a large scale, randomized, controlled, parallel-group trial-design and rationale. Respir Res. 2013;14:40.

28. Karner C, Chong J, Poole P. Tiotropium versus placebo for chronic obstructive pulmonary disease. Cochrane Database Syst Rev. 2014;7:CD009285.

29. Halpin DMG, Vogelmeier C, Pieper MP, Metzdorf N, Richard F, Anzueto A. Effect of tiotropium on COPD exacerbations: A systematic review. Respir Med. 2016;114:1-8.

30. Ismaila AS, Huisman EL, Punekar YS, Karabis A. Comparative efficacy of long-acting muscarinic antagonist monotherapies in COPD: a systematic review and network meta-analysis. Int J Chron Obstruct Pulmon Dis. 2015; 10:2495-517.

31. Tricco AC, Strifler L, Veroniki AA et al. Comparative safety and effectiveness of long-acting inhaled agents for treating chronic obstructive pulmonary disease: a systematic review and network meta-analysis. BMJ Open. 2015;5:e009183.

32. Halpin D, Menjoge S, Viel K. Patient-level pooled analysis of the effect of tiotropium on COPD exacerbations and related hospitalisations. Prim Care Respir J. 2009;18:106-13

33. Yohannes AM, Willgoss TG, Vestbo J. Tiotropium for treatment of stable COPD: a meta-analysis of clinically relevant outcomes. Respir Care. 2011;56:477-87.

34. Chong J, Karner C, Poole P. Tiotropium versus long-acting beta-agonists for stable chronic obstructive pulmonary disease. Cochrane Database Syst Rev. 2012;9:CD009157.

35. Dong YH, Lin HH, Shau WY, Wu YC, Chang CH, Lai MS. Comparative safety of inhaled medications in patients with chronic obstructive pulmonary disease: systematic review and mixed treatment comparison meta-analysis of randomised controlled trials. Thorax. 2013;68:48-56.

36. Halpin DM, Dahl R, Hallmann C, Mueller A, Tashkin D. Tiotropium HandiHaler((R)) and Respimat $((\mathrm{R}))$ in COPD: a pooled safety analysis. Int J Chron Obstruct Pulmon Dis. 2015;10:239-59.

37. Tashkin DP, Celli B, Senn S et al. A 4-year trial of tiotropium in chronic obstructive pulmonary disease. N Engl J Med. 2008;359:1543-54.

38. Halpin DMG, Tashkin D, Celli B, Leimer I, Metzdorf N, Decramer M. Effect of Tiotropium on Outcomes in Patients With COPD, Categorized Using the New GOLD Grading System: Results of the UPLIFT® Randomized Controlled Trial. Chronic Obstr Pulm Dis (Miami). 2015;2:236-51.

39. Keating GM. Tiotropium bromide inhalation powder: a review of its use in the management of chronic obstructive pulmonary disease. Drugs. 2012;72:273-300.

40. Wise RA, Anzueto A, Cotton D et al. Tiotropium Respimat Inhaler and the Risk of Death in COPD. N Engl J Med. 2013; 369:1491-501.

41. O'Donnell DE, Fluge T, Gerken F et al. Effects of tiotropium on lung hyperinflation, dyspnoea and exercise tolerance in COPD. Eur Respir J. 2004;23: 832-40.

42. Tashkin DP, Celli B, Kesten S, Lystig T, Mehra S, Decramer M. Long-term efficacy of tiotropium in relation to smoking status in the UPLIFT trial. Eur Respir J. 2010;35:287-94
43. Decramer M, Celli B, Kesten S, Lystig T, Mehra S, Tashkin DP. Effect of tiotropium on outcomes in patients with moderate chronic obstructive pulmonary disease (UPLIFT): a prespecified subgroup analysis of a randomised controlled trial. Lancet. 2009;374:1171-8.

44. Donohue JF, van Noord JA, Bateman ED et al. A 6-month, placebo-controlled study comparing lung function and health status changes in COPD patients treated with tiotropium or salmeterol. Chest. 2002;122:47-55.

45. Decramer ML, Chapman KR, Dahl R et al. Once-daily indacaterol versus tiotropium for patients with severe chronic obstructive pulmonary disease (INVIGORATE): a randomised, blinded, parallel-group study. Lancet Respir Med. 2013;1:524-33.

46. Kerwin E, Hebert J, Gallagher N et al. Efficacy and safety of NVA237 versus placebo and tiotropium in patients with COPD: the GLOW2 study. Eur Respir J. 2012;40:1106-14.

47. Beier J, Kirsten AM, Mroz R et al. Efficacy and safety of aclidinium bromide compared with placebo and tiotropium in patients with moderate-to-severe chronic obstructive pulmonary disease: results from a 6-week, randomized, controlled Phase IIIb study. Copd. 2013;10:511-22.

48. Chapman KR, Beeh KM, Beier J et al. A blinded evaluation of the efficacy and safety of glycopyrronium, a once-daily long-acting muscarinic antagonist, versus tiotropium, in patients with COPD: the GLOW5 study. BMC Pulm Med. 2014;14:4.

49. Feldman G, Maltais F, Khindri S et al. A randomized, blinded study to evaluate the efficacy and safety of umeclidinium 62.5 mug compared with tiotropium 18 mug in patients with COPD. Int J Chron Obstruct Pulmon Dis. 2016;11:719-30.

50. Kaplan A. Effect of tiotropium on quality of life in COPD: a systematic review. Prim Care Respir J. 2010;19:315-25.

51. Morice AH, Celli B, Kesten S, Lystig T, Tashkin D, Decramer M. COPD in young patients: a pre-specified analysis of the four-year trial of tiotropium (UPLIFT). Respir Med. 2010;104:1659-67.

52. Halpin DM, Miravitlles M, Metzdorf N, Celli B. Impact and prevention of severe exacerbations of COPD: a review of the evidence. Int J Chron Obstruct Pulmon Dis. 2017;12:2891-908.

53. Chu EK, Whitehead T, Slutsky AS. Effects of cyclic opening and closing at low- and high-volume ventilation on bronchoalveolar lavage cytokines. Crit Care Med. 2004;32:168-74.

54. Washko GR, Fan VS, Ramsey SD et al. The effect of lung volume reduction surgery on chronic obstructive pulmonary disease exacerbations. Am J Respir Crit Care Med. 2008;177:164-9.

55. Niewoehner DE, Rice K, Cote $C$ et al. Prevention of exacerbations of chronic obstructive pulmonary disease with tiotropium, a once-daily inhaled anticholinergic bronchodilator: a randomized trial. Ann Intern Med. 2005; 143:317-26.

56. Buhling F, Lieder N, Kuhlmann UC, Waldburg N, Welte T. Tiotropium suppresses acetylcholine-induced release of chemotactic mediators in vitro. Respir Med. 2007;101:2386-94.

57. Vogelmeier C, Hederer B, Glaab T et al. Tiotropium versus salmeterol for the prevention of exacerbations of COPD. N Engl J Med. 2011;364:1093-103.

58. Vogelmeier C, Fabbri LM, Rabe KF et al. Effect of tiotropium vs. salmeterol on exacerbations: GOLD II and maintenance therapy naive patients Respir Med. 2013;107:75-83.

59. Wedzicha JA, Calverley PM, Seemungal TA, Hagan G, Ansari Z, Stockley RA. The prevention of chronic obstructive pulmonary disease exacerbations by salmeterol/fluticasone propionate or tiotropium bromide. Am J Respir Crit Care Med. 2008;177:19-26.

60. Celli B, Decramer M, Leimer I, Vogel U, Kesten S, Tashkin DP. Cardiovascular safety of tiotropium in patients with COPD. Chest. 2010;137:20-30.

61. Casaburi R, Kukafka D, Cooper CB, Witek TJ, Jr., Kesten S. Improvement in exercise tolerance with the combination of tiotropium and pulmonary rehabilitation in patients with COPD. Chest. 2005;127:809-17.

62. Maltais F, Hamilton A, Marciniuk D et al. Improvements in symptom-limited exercise performance over $8 \mathrm{~h}$ with once-daily tiotropium in patients with COPD. Chest. 2005;128:1168-78. 
63. Cooper CB, Celli BR, Jardim JR et al. Treadmill Endurance During 2-Year Treatment With Tiotropium in Patients With COPD: A Randomized Trial. Chest. 2013;144:490-7.

64. Verkindre C, Bart F, Aguilaniu B et al. The effect of tiotropium on hyperinflation and exercise capacity in chronic obstructive pulmonary disease. Respiration. 2006;73:420-7.

65. Alagha K, Palot A, Sofalvi T et al. Long-acting muscarinic receptor antagonists for the treatment of chronic airway diseases. Ther Adv Chronic Dis. 2014;5:85-98.

66. Babu KS, Morjaria JB. Umeclidinium in chronic obstructive pulmonary disease: latest evidence and place in therapy. Ther Adv Chronic Dis. 2017;8: 81-91.

67. Ni H, Htet A, Moe S. Umeclidinium bromide versus placebo for people with chronic obstructive pulmonary disease (COPD). Cochrane Database Syst Rev. 2017;6:CD011897.

68. Pleasants RA, Wang T, Gao J, Tang H, Donohue JF. Inhaled Umeclidinium in COPD Patients: A Review and Meta-Analysis. Drugs. 2016;76:343-61.

69. Dransfield MT, Bailey W, Crater G, Emmett A, O'Dell DM, Yawn B. Disease severity and symptoms among patients receiving monotherapy for COPD. Prim Care Respir J. 2011;20:46-53.

70. Muruganandan S, Jayaram L. Profile of a fixed-dose combination of tiotropium/olodaterol and its potential in the treatment of COPD. Int J Chron Obstruct Pulmon Dis. 2015;10:1179-89.

71. Ramadan WH, Kabbara WK, El Khoury GM, Al Assir SA. Combined bronchodilators (tiotropium plus olodaterol) for patients with chronic obstructive pulmonary disease. Int J Chron Obstruct Pulmon Dis. 2015;10:2347-56.

72. Beeh KM, Westerman J, Kirsten AM et al. The 24-h lung-function profile of once-daily tiotropium and olodaterol fixed-dose combination in chronic obstructive pulmonary disease. Pulm Pharmacol Ther. 2015;32:53-9.

73. Buhl R, Maltais F, Abrahams R et al. Tiotropium and olodaterol fixed-dose combination versus mono-components in COPD (GOLD 2-4). Eur Respir J. 2015;45:969-79

74. Ferguson GT, Flezar M, Korn S et al. Efficacy of Tiotropium + Olodaterol in Patients with Chronic Obstructive Pulmonary Disease by Initial Disease Severity and Treatment Intensity: A Post Hoc Analysis. Adv Ther. 2015;32: 523-36.

75. Singh D, Ferguson GT, Bolitschek J et al. Tiotropium + olodaterol shows clinically meaningful improvements in quality of life. Respir Med. 2015;109: 1312-9.

76. Magnussen H, Watz H, Kirsten A et al. Stepwise withdrawal of inhaled corticosteroids in COPD patients receiving dual bronchodilation: WISDOM study design and rationale. Respir Med. 2014; 108:593-9.

77. Calverley PMA, Tetzlaff K, Vogelmeier C et al. Eosinophilia, Frequent Exacerbations, and Steroid Response in Chronic Obstructive Pulmonary Disease. Am J Respir Crit Care Med. 2017;196:1219-21.

78. Demoly P, Paggiaro P, Plaza V et al. Prevalence of asthma control among adults in France, Germany, Italy, Spain and the UK. Eur Respir Rev. 2009; $18: 105-12$.

79. Canonica GW, Baena-Cagnani CE, Blaiss MS, Dahl R, Kaliner MA, Valovirta EJ. Unmet needs in asthma: Global Asthma Physician and Patient (GAPP) Survey: global adult findings. Allergy. 2007;62:668-74.

80. Liu AH, Gilsenan AW, Stanford RH, Lincourt W, Ziemiecki R, Ortega H. Status of asthma control in pediatric primary care: results from the pediatric Asthma Control Characteristics and Prevalence Survey Study (ACCESS). J Pediatr. 2010; 157:276-81 e3.

81. Bateman ED, Boushey HA, Bousquet J et al. Can guideline-defined asthma control be achieved? The Gaining Optimal Asthma ControL study. Am J Respir Crit Care Med. 2004;170:836-44.

82. Moulton BC, Fryer AD. Muscarinic receptor antagonists, from folklore to pharmacology; finding drugs that actually work in asthma and COPD. Br J Pharmacol. 2011;163:44-52.

83. O'Connor BJ, Towse LJ, Barnes PJ. Prolonged effect of tiotropium bromide on methacholine-induced bronchoconstriction in asthma. Am J Respir Crit Care Med. 1996;154:876-80.
84. Peters SP, Kunselman SJ, Icitovic N et al. Tiotropium bromide step-up therapy for adults with uncontrolled asthma. N Engl J Med. 2010;363:1715-26.

85. Bateman ED, Kornmann O, Schmidt P, Pivovarova A, Engel M, Fabbri LM. Tiotropium is noninferior to salmeterol in maintaining improved lung function in B16-Arg/Arg patients with asthma. J Allergy Clin Immunol. 2011; 128:315-22.

86. Beeh KM, Moroni-Zentgraf P, Ablinger O et al. Tiotropium Respimat(R) in asthma: a double-blind, randomised, dose-ranging study in adult patients with moderate asthma. Respir Res. 2014;15:61.

87. Beeh KM, Kirsten AM, Dusser D et al. Pharmacodynamics and Pharmacokinetics Following Once-Daily and Twice-Daily Dosing of Tiotropium Respimat(R) in Asthma Using Standardized Sample-Contamination Avoidance. J Aerosol Med Pulm Drug Deliv. 2016;29:406-15.

88. Hamelmann E, Bateman ED, Vogelberg C et al. Tiotropium add-on therapy in adolescents with moderate asthma: A 1-year randomized controlled trial. J Allergy Clin Immunol. 2016;138:441-450.

89. Kerstjens HA, Disse B, Schroder-Babo W et al. Tiotropium improves lung function in patients with severe uncontrolled asthma: a randomized controlled trial. J Allergy Clin Immunol. 2011;128:308-14.

90. Kerstjens HA, Engel M, Dahl R et al. Tiotropium in asthma poorly controlled with standard combination therapy. N Engl J Med. 2012;367:1198-207.

91. Kerstjens HA, Casale TB, Bleecker ER et al. Tiotropium or salmeterol as add-on therapy to inhaled corticosteroids for patients with moderate symptomatic asthma: two replicate, double-blind, placebo-controlled, parallel-group, active-comparator, randomised trials. Lancet Respir Med. 2015;3: 367-76.

92. Paggiaro P, Halpin DM, Buhl R et al. The Effect of Tiotropium in Symp tomatic Asthma Despite Low- to Medium-Dose Inhaled Corticosteroids: A Randomized Controlled Trial. J Allergy Clin Immunol Pract. 2016;4:104-13

93. Ohta K, Ichinose M, Tohda Y et al. Long-Term Once-Daily Tiotropium Respimat(R) Is Well Tolerated and Maintains Efficacy over 52 Weeks in Patients with Symptomatic Asthma in Japan: A Randomised, Placebo-Controlled Study. PLoS One. 2015;10:e0124109.

94. Timmer W, Moroni-Zentgraf P, Cornelissen P, Unseld A, Pizzichini E, Buhl R. Once-daily tiotropium Respimat((R)) 5 mug is an efficacious 24-h bronchodilator in adults with symptomatic asthma. Respir Med. 2015;109: 329-38.

95. Vogelberg C, Engel M, Moroni-Zentgraf P, Leonaviciute-Klimantaviciene M, Sigmund R, Downie J, et al. Tiotropium in asthmatic adolescents symptomatic despite inhaled corticosteroids: a randomised dose-ranging study. Respir Med. 2014;108:1268-76.

96. Vogelberg C, Moroni-Zentgraf P, Leonaviciute-Klimantaviciene $\mathrm{M}$ et al. A randomised dose-ranging study of tiotropium $\operatorname{Respimat}(\mathrm{R})$ in children with symptomatic asthma despite inhaled corticosteroids. Respir Res. 2015;16:20.

97. Szefler SJ, Murphy K, Harper T et al. A phase III randomized controlled trial of tiotropium add-on therapy in children with severe symptomatic asthma. J Allergy Clin Immunol. 2017;140:1277-87.

98. Hamelmann E, Bernstein JA, Vandewalker M et al. A randomised controlled trial of tiotropium in adolescents with severe symptomatic asthma. Eur Respir J. 2017;49.

99. Halpin DM. Tiotropium in asthma: what is the evidence and how does it fit in? World Allergy Organ J. 2016;9:29.

100. Lee SW, Kim HJ, Yoo KH et al. Long-acting anticholinergic agents in patients with uncontrolled asthma: a systematic review and meta-analysis. Int J Tuberc Lung Dis. 2014;18:1421-30.

101. Rodrigo GJ, Neffen H. Efficacy and safety of tiotropium in school-age children with moderate-to-severe symptomatic asthma: A systematic review. Pediatr Allergy Immunol. 2017;28:573-8.

102. Rodrigo GJ, Castro-Rodriguez JA. What is the role of tiotropium in asthma?: a systematic review with meta-analysis. Chest. 2015;147:388-96.

103. Kerstjens HA, Moroni-Zentgraf P, Tashkin DP et al. Tiotropium improves lung function, exacerbation rate, and asthma control, independent of baseline characteristics including age, degree of airway obstruction, and allergic status. Respir Med. 2016;117:198-206 
104. Casale TB, Bateman ED, Vandewalker M et al. Tiotropium Respimat Addon Is Efficacious in Symptomatic Asthma, Independent of T2 Phenotype. J Allergy Clin Immunol Pract. 2017.

105. Price D, Kaplan A, Jones R et al. Long-acting muscarinic antagonist use in adults with asthma: real-life prescribing and outcomes of add-on therapy with tiotropium bromide. J Asthma Allergy. 2015;8:1-13..

106. Willson J, Bateman ED, Pavord I, Lloyd A, Krivasi T, Esser D. Cost effectiveness of tiotropium in patients with asthma poorly controlled on inhaled glucocorticosteroids and long-acting beta-agonists. Appl Health Econ Health Policy. 2014;12:447-59.

107. Global Initiative for Asthma. Global strategy for asthma management and prevention. (updated 2016) 2016. Available from: http://www.ginasthma.org.

108. Ciciliani AM, Langguth $\mathrm{P}$, Wachtel $\mathrm{H}$. In vitro dose comparison of Respimat(R) inhaler with dry powder inhalers for COPD maintenance therapy. Int J Chron Obstruct Pulmon Dis. 2017;12:1565-77.

109. Caillaud D, Le Merre C, Martinat Y, Aguilaniu B, Pavia D. A dose-ranging study of tiotropium delivered via Respimat Soft Mist Inhaler or HandiHaler in COPD patients. Int J Chron Obstruct Pulmon Dis. 2007;2:559-65.

110. Hohlfeld JM, Sharma A, van Noord JA et al. Pharmacokinetics and pharmacodynamics of tiotropium solution and tiotropium powder in chronic obstructive pulmonary disease. J Clin Pharmacol. 2014;54:405-14.

111. Price D, Sharma A, Cerasoli F. Biochemical properties, pharmacokinetics and pharmacological response of tiotropium in chronic obstructive pulmonary disease patients. Expert Opin Drug Metab Toxicol. 2009;5:417-24.

112. Celli B, Decramer M, Leimer I, Vogel U, Kesten S, Tashkin DP. Cardiovascular Safety of Tiotropium in Patients With COPD. Chest. 2010;137:20-30.

113. Wang M-T, Liou J-T, Lin CW et al. Association of Cardiovascular Risk With Inhaled Long-Acting Bronchodilators in Patients With Chronic Obstructive Pulmonary Disease. A Nested Case-Control Study. JAMA Intern Med. 2018;178.

114. Dahl R, Engel M, Dusser D et al. Safety and tolerability of once-daily tiotropium Respimat $((\mathrm{R}))$ as add-on to at least inhaled corticosteroids in adult patients with symptomatic asthma: A pooled safety analysis. Respir Med. 2016;118:102-11.

115. Brusasco V, Hodder R, Miravitlles M, Korducki L, Towse L, Kesten S. Health outcomes following treatment for six months with once daily tiotro- pium compared with twice daily salmeterol in patients with COPD. Thorax. 2003;58:399-404.

116. Casaburi R, Mahler DA, Jones PW et al. A long-term evaluation of once-daily inhaled tiotropium in chronic obstructive pulmonary disease. Eur Respir J. 2002;19:217-24.

117. Chan CK, Maltais F, Sigouin C, Haddon JM, Ford GT. A randomized controlled trial to assess the efficacy of tiotropium in Canadian patients with chronic obstructive pulmonary disease. Can Respir J. 2007;14:465-72.

118. Tonnel AB, Perez T, Grosbois JM, Verkindre C, Bravo ML, Brun M. Effect of tiotropium on health-related quality of life as a primary efficacy endpoint in COPD. Int J Chron Obstruct Pulmon Dis. 2008;3:301-10.

119. Dusser D, Bravo ML, Iacono P. The effect of tiotropium on exacerbations and airflow in patients with COPD. Eur Respir J. 2006;27:547-55.

120. Johansson G, Lindberg A, Romberg K, Nordstrom L, Gerken F, Roquet A Bronchodilator efficacy of tiotropium in patients with mild to moderate COPD. Prim Care Respir J. 2008;17:169-75.

121. Freeman D, Lee A, Price D. Efficacy and safety of tiotropium in COPD patients in primary care--the SPiRiva Usual CarE (SPRUCE) study. Respir Res. 2007;8:45.

122. van Noord JA, Cornelissen PJ, Aumann JL, Platz J, Mueller A, Fogarty C. The efficacy of tiotropium administered via Respimat Soft Mist Inhaler or HandiHaler in COPD patients. Respir Med. 2009;103:22-9.

123. Troosters T, Sciurba FC, Decramer M, Siafakas NM, Klioze SS, Sutradhar SC, et al. Tiotropium in patients with moderate COPD naive to maintenance therapy: a randomised placebo-controlled trial. NPJ Prim Care Respir Med. 2014;24:14003.

124. Zhou Y, Zhong NS, Li X et al. Tiotropium in Early-Stage Chronic Obstructive Pulmonary Disease. N Engl J Med. 2017;377:923-35.

125. Voshaar T, Lapidus R, Maleki-Yazdi R et al. A randomized study of tiotropium Respimat Soft Mist inhaler vs. ipratropium pMDI in COPD. Respir Med. 2008;102:32-41.

126. Bateman E, Singh D, Smith D et al. Efficacy and safety of tiotropium Respimat SMI in COPD in two 1-year randomized studies. Int J Chron Obstruct Pulmon Dis. 2010;5:197-208.

127. Bateman ED, Tashkin D, Siafakas N et al. A one-year trial of tiotropium Respimat plus usual therapy in COPD patients. Respir Med. 2010;104:1460-72. 